\title{
THE EFFECTS OF SILVER NANOPARTICLES ON GROWTH OF Chrysanthemum morifolium Ramat. cv. "JIMBA" IN DIFFERENT CULTURAL SYSTEMS
}

\author{
Luong Thien Nghia ${ }^{1}$, Hoang Thanh Tung ${ }^{1,2}$, Nguyen Phuc Huy ${ }^{1}$, \\ Vu Quoc Luan ${ }^{1}$, Duong Tan Nhut ${ }^{1}$ ** \\ ${ }^{1}$ Tay Nguyen Institute for Scientific Research, VAST, 116 Xo Viet Nghe Tinh, Da Lat, Lam Dong \\ ${ }^{2}$ Hue University of Sciences, Hue University, 77 Nguyen Hue, Hue, Thua Thien - Hue \\ "Email:duongtannhut@gmail.com
}

Received: 14 March 2017; Accepted for publication: 31 July 2017

\begin{abstract}
Silver nanoparticles (SNPs) are one of metallic nanoparticles widely applied in many fields. Research of SNPs application in plant tissue culture has been gaining attention in recent years. Moreover, novel plant tissue culture systems have been researched and developed for improving SNPs uptake capability in medium. In this study, we investigated effects of SNPs on Chrysanthemum morifolium ramat. cv. "JIMBA" growth and its ability in 3 culture systems: in vitro solid medium system, in vitro liquid medium system and microponic (combined of micropropagation and hydroponic). The $3 \mathrm{~cm}$ Chrysanthemum shoots and silver nanoparticles of diameter smaller than $20 \mathrm{~nm}$ were used in the experiments. After 4 weeks, the results showed that the SNPs concentration was suitable for growth of Chrysanthemum in vitro solid medium system, in vitro liquid medium system and microponic was $1.5,1.5$ and $5 \mathrm{ppm}$, respectively. Microponic system not only improved plant growth but also reduced the succulent phenomenon. SNP uptake was likely dependent on concentrations and culture systems. At low concentrations $(1,5$, and $10 \mathrm{ppm})$, SNPs were completely absorbed after 4 weeks of culture in all systems, but not at high concentrations $(20 \mathrm{ppm})$. The amount of absorbed silver nanoparticles was directly proportional to the culture period and inversely proportional to the concentration of SNPs supplemented to the medium. In all of our investigated systems, the hydroponic system showed the highest capability of SNPs absorption.
\end{abstract}

Keywords: absorption, Chrysanthemum sp., growth, microponic, silver nanoparticles.

\section{INTRODUCTION}

The rapid growth of nanotechnology make it become one of the greatest impetuses to technological and industrial development in the $21^{\text {st }}$ century. Among the different type of nanomaterials, silver nanoparticles (SNPs) are extensively used in many fields of science and technology. In plant tissue culture technology, SNPs were applied as a factor which may resist some inhibitors in micro-propagation, such as in vitro contamination (e.g., fungal and bacterial infections) $[1,2,3,4,5,6]$ and ethylene $[7,8,9]$, hence, improve in vitro plant growth. In recent 
years, nanoparticles absorption mechanisms have gained first attentions, experiments demonstrated SNPs can be absorbed via leafs or roots [10] by penetrated or diffused in symplast and apoplast [11]. Otherwise, cultural conditions are the most important factors which directly impact to nanoparticle absorption. Kumari et al. proved that in liquid medium metal nanoparticles are absorbed more effectively than in solid or semi-solid medium [12]. On the other hand, ventilation condition between inside and outside system is an advantage factor for uptake nutrient from medium due to enhancing transpiration capability. Nevertheless, studying about conditions effect on SNPs absorption is still quite limited. Therefore, the targets in this experiment aim to investigate effect of SNPs on Chrysanthemum sp. growth in various cultural systems and find out which system is appropriate to SNPs absorption.

\section{MATERIALS AND METHODS}

\subsection{Sample source and materials}

Chrysanthemum morifolium shoots with $3 \mathrm{~cm}$ in length were used as explant source. These shoots were obtained from a mass of shoots cultured in vitro on Murashige and Skoog (MS) medium [13] with $8 \mathrm{~g} / \mathrm{L}$ agar and $30 \mathrm{~g} / \mathrm{l}$ sucrose after $40-45$ days of culture.

The used silver nanoparticles (SNPs) were of size smaller than $20 \mathrm{~nm}$ which had been manufactured using the rate: $\left[\mathrm{AgNO}_{3}\right]=750-1000 \mathrm{ppm},[\beta$-chitosan $]=250-300 \mathrm{ppm}$, $\left[\mathrm{NaBH}_{4}\right]=200 \mathrm{ppm}$, mole rate $\left[\mathrm{NaBH}_{4}\right] /\left[\mathrm{AgNO}_{3}\right]=1 / 4, \mathrm{NaBH}_{4}$ drip speed: $10-12 \mathrm{droplet} / \mathrm{min}$.

Substrates in microponic and in vitro liquid medium systems are tubes of nylon films with $2 \mathrm{~cm}$ in height and $1.5 \mathrm{~cm}$ in diameter. Substrates were put into the cultural vessels (bottles or plastic box).

\subsection{Cultural systems}

\subsubsection{In vitro with solid or liquid medium systems}

Glass bottles with $250 \mathrm{ml}$ in volume, each of bottles contain $40 \mathrm{ml}$ of MS medium, with 30 $\mathrm{g} / \mathrm{l}$ sucrose (and supplied $8 \mathrm{~g} / \mathrm{l}$ agar in solid medium system). After that, we supplied SNPs of various concentrations and sterilized by autoclaving at $121{ }^{\circ} \mathrm{C}, 1 \mathrm{~atm}$ in 30 minutes.

\subsubsection{Microponic system}

Microponic system was circular plastic containers with $12 \mathrm{~cm}$ of diameter at top, $9 \mathrm{~cm}$ of diameter at bottom, and $8.5 \mathrm{~cm}$ of height. $40 \mathrm{ml}$ of half-strength sugar-free liquid MS medium was added to system with 15 tubes of nylon film. Top of the system was equipped with one Millipore filter by Milliseal ${ }^{\mathrm{TM}}$, of pore size of $0.2 \mu \mathrm{m}$ (Nihon Millipore Ltd., Tokyo, Japan).

All experiments were incubated at $25 \pm 2{ }^{\circ} \mathrm{C}$ with humidity of $55-60 \%$ and photoperiod of 12 hours/day under fluorescent light with $45 \mu \mathrm{mol} . \mathrm{m}^{-2} \cdot \mathrm{s}^{-1}$ of intensity.

\subsection{Methods}

\subsubsection{Evaluating effect of SNPs to Chrysanthemum growth on in vitro solid medium system}

Shoots were cultured in in vitro solid medium system within different SNPs concentrations $(0 ; 0,5 ; 1 ; 1,5 ; 2 ; 3 ; 5 ; 7 ; 10 \mathrm{ppm})$ and sterilized in autoclave to investigate effects of SNPs on Chrysanthemum growth. 


\subsubsection{Evaluating effect of SNPs to Chrysanthemum growth on in vitro liquid medium system}

Shoots were cultured in in vitro liquid medium system within different SNPs concentrations $(0 ; 0.5 ; 1 ; 1.5 ; 2 ; 3 ; 5 ; 7 ; 10 \mathrm{ppm})$ and sterilized in autoclave to investigate effects of SNPs on Chrysanthemum growth.

\subsubsection{Evaluating effect of SNPs to Chrysanthemum growth on microponic system}

Shoots were cultured in microponic system within different SNPs concentrations $(0 ; 5 ; 10$; $15 ; 20 \mathrm{ppm})$ without sterilization to investigate effects of SNPs on Chrysanthemum growth.

\subsubsection{Evaluating absorption capability of different systems}

Shoots were cultured in different culture systems (in vitro solid medium, in vitro liquid medium and microponic system) with various SNPs concentrations $(1 ; 5 ; 10 ; 20 \mathrm{ppm})$. After 1, 2, 3, 4 weeks, medium remained was collected and SNPs content in culture medium was examined to determine absorbed-SNPs contents.

\subsection{Collecting and analysing data}

Data were scored in 4 weeks of culturing and analysis of variance was performed. Investigated growth characteristic include: Plant height $(\mathrm{mm})$; number of shoots; number of leaves; number of roots, root length (mm); SPAD - total chlorophyll content $(\mu \mathrm{g} / \mathrm{g})$, fresh weight (mg); dry weight (mg); net weight rate (\%), absorbed-SNPs rate (\%).

Total chlorophyll contents in leaves were evaluated by SPAD-502 (Minolta Co., Ltd., Osaka, Japan). SNPs contents in medium were evaluated by UV-vis spectroscopic at $480 \mathrm{~nm}$ [14] of wavelength (Shimadzu, UV-2450, Japan). Root morphology were observed by Nikon SMZ 800 (Nikon, Japan) in 20x of magnify rate.

Net weight rates were calculated by the following formula:

$$
\text { Net weight rate }(\%)=\frac{\text { Dry weight }(\mathrm{mg})}{\text { Fresh weight }(\mathrm{mg})} \times 100 \%
$$

Absorbed-SNP rates were calculated by the following formula:

$$
\operatorname{AgH}(\%)=\frac{\operatorname{Ag} 0-\operatorname{AgT}}{\operatorname{Ag} 0} \times 100 \%
$$

where: AgH is absorbed-SNPs rates after (1, 2, 3, 4 weeks) (\%),

$\mathrm{Ag} 0$ is total SNPs content in culture medium at the beginning (mg),

$\mathrm{AgT}$ is total SNPs content in culture medium at 1, 2, 3, 4 weeks (mg).

All treatments were in triplicates and each replicate with 10 culture vessel. The means were compared using Duncan's multiple range Test using SPSS (Version 16.0) at $\alpha=0.05$ [15].

\section{RESULTS AND DISCUSSION}

\subsection{Effects of SNP on Chrysanthemum growth in in vitro solid medium system}


The effects of exposure to different concentrations of SNPs on Chrysanthemum plantlets after four weeks of incubation are presented in Table 1 and Figure 1.

Table 1. Effects of SNP on chrysanthemum growth in in vitro solid medium system.

\begin{tabular}{llllllllll}
\hline $\begin{array}{c}\text { SNP } \\
(\mathrm{ppm})\end{array}$ & $\begin{array}{c}\text { No. } \\
\text { of shoots }\end{array}$ & $\begin{array}{c}\text { Plant } \\
\text { height } \\
(\mathrm{mm})\end{array}$ & $\begin{array}{c}\text { No. } \\
\text { of leaves }\end{array}$ & $\begin{array}{c}\text { No. } \\
\text { of roots }\end{array}$ & $\begin{array}{c}\text { Root } \\
\text { length } \\
(\mathrm{mm})\end{array}$ & $\begin{array}{c}\text { SPAD } \\
(\mathrm{mg} / \mathrm{g})\end{array}$ & $\begin{array}{c}\text { Fresh } \\
\text { weight } \\
(\mathrm{mg})\end{array}$ & $\begin{array}{c}\text { Dry } \\
\text { weight } \\
(\mathrm{mg})\end{array}$ & $\begin{array}{c}\text { Net weight } \\
\text { rate }(\%)\end{array}$ \\
\hline 0 & $6.3^{\mathrm{bcd}}$ & $39.7^{\mathrm{bc}}$ & $10.3^{\mathrm{a}}$ & $8.7^{\mathrm{c}}$ & $49.7^{\mathrm{bcd}}$ & $31.9^{\mathrm{b}}$ & $300.3^{\mathrm{b}}$ & $14.0^{\mathrm{e}}$ & $4.66^{\mathrm{a}}$ \\
\hline 0.5 & $6.3^{\mathrm{bcd}}$ & $39.0^{\mathrm{bc}}$ & $8.3^{\mathrm{bcd}}$ & $8.0^{\mathrm{c}}$ & $45.0^{\mathrm{d}}$ & $32.7^{\mathrm{b}}$ & $328.0^{\mathrm{b}}$ & $19.0^{\text {de }}$ & $5.79^{\mathrm{a}}$ \\
\hline 1 & $7.3^{\mathrm{b}}$ & $44.7^{\mathrm{ab}}$ & $8.7^{\mathrm{abc}}$ & $14.0^{\mathrm{abc}}$ & $45.3^{\mathrm{d}}$ & $31.7^{\mathrm{b}}$ & $531.0^{\mathrm{a}}$ & $31.0^{\mathrm{c}}$ & $5.84^{\mathrm{a}}$ \\
\hline 1.5 & $9.0^{\mathrm{a}}$ & $48.3^{\mathrm{a}}$ & $10.0^{\mathrm{ab}}$ & $17.3^{\mathrm{a}}$ & $65.0^{\mathrm{a}}$ & $37.6^{\mathrm{a}}$ & $673.7^{\mathrm{a}}$ & $58.7^{\mathrm{a}}$ & $8.71^{\mathrm{a}}$ \\
\hline 2 & $6.7^{\mathrm{bc}}$ & $42.0^{\mathrm{ab}}$ & $8.0^{\mathrm{bcd}}$ & $16.7^{\mathrm{ab}}$ & $62.0^{\mathrm{abc}}$ & $34.0^{\mathrm{ab}}$ & $657.3^{\mathrm{a}}$ & $46.0^{\mathrm{b}}$ & $7.00^{\mathrm{a}}$ \\
\hline 3 & $6.7^{\mathrm{bc}}$ & $34.7^{\mathrm{cd}}$ & $9.7^{\mathrm{abc}}$ & $13.7^{\mathrm{abc}}$ & $62.2^{\mathrm{abc}}$ & $32.5^{\mathrm{b}}$ & $354.3^{\mathrm{b}}$ & $27.3^{\mathrm{cd}}$ & $7.71^{\mathrm{a}}$ \\
\hline 5 & $5.3^{\mathrm{cd}}$ & $32.0^{\mathrm{d}}$ & $6.3^{\mathrm{e}}$ & $10.3^{\mathrm{bc}}$ & $53.7^{\mathrm{bcd}}$ & $31.7^{\mathrm{b}}$ & $188.7^{\mathrm{b}}$ & $15.3^{\mathrm{e}}$ & $8.13^{\mathrm{a}}$ \\
\hline 7 & $5.7^{\mathrm{bcd}}$ & $42.7^{\mathrm{ab}}$ & $7.7^{\mathrm{cde}}$ & $11.7^{\mathrm{abc}}$ & $64.3^{\mathrm{ab}}$ & $34.9^{\mathrm{ab}}$ & $342.7^{\mathrm{b}}$ & $22.0^{\text {cde }}$ & $6.42^{\mathrm{a}}$ \\
\hline 10 & $4.7^{\mathrm{d}}$ & $31.7^{\mathrm{d}}$ & $7.0^{\mathrm{de}}$ & $10.7^{\mathrm{bc}}$ & $48.3^{\mathrm{d}}$ & $32.3^{\mathrm{b}}$ & $228.3^{\mathrm{b}}$ & $14.3^{\mathrm{e}}$ & $6.28^{\mathrm{a}}$ \\
\hline
\end{tabular}

Different letters within a column indicate significant differences at $\alpha=0.05$ by Duncan's multiple range tests.

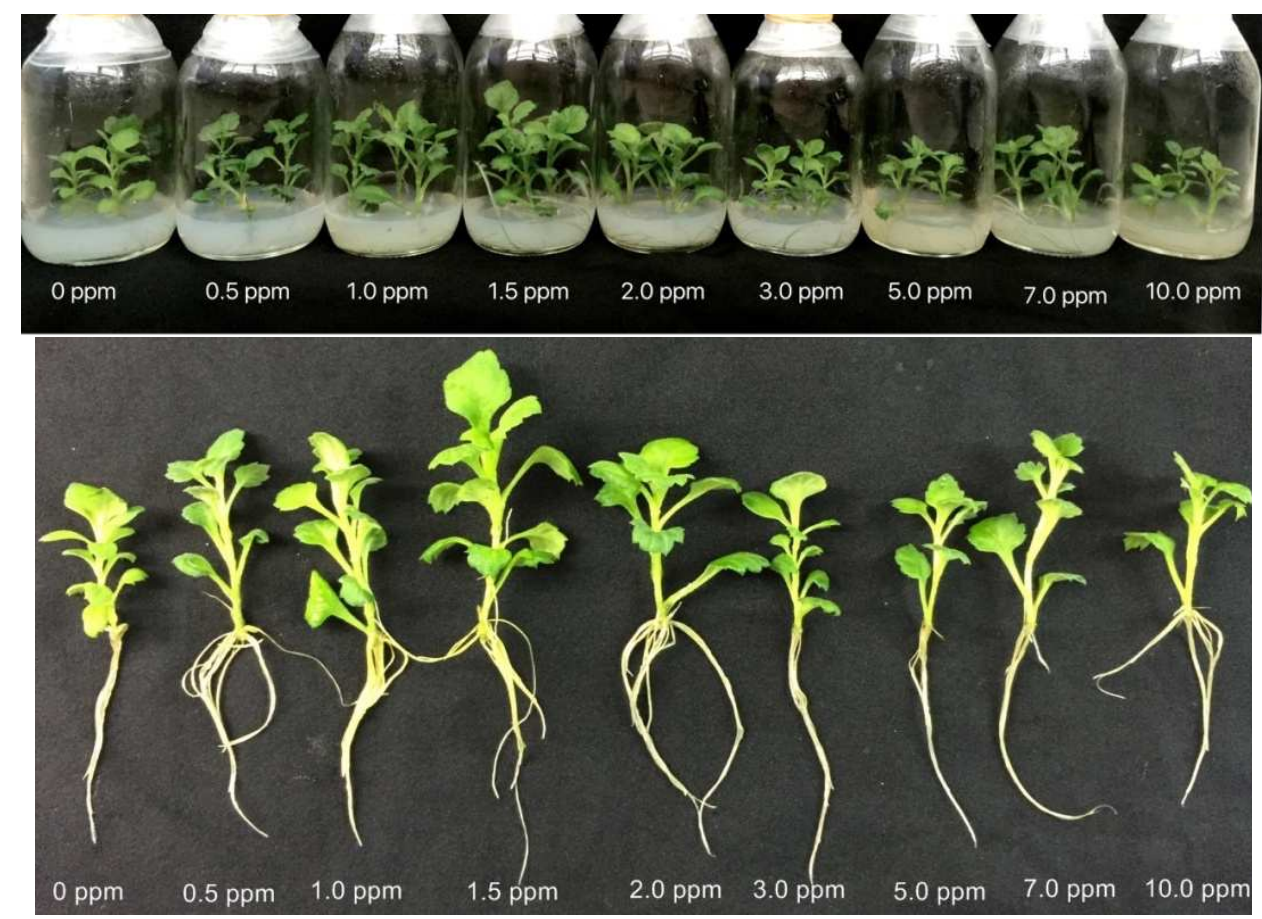

Figure 1. Effects of SNPs on Chrysanthemum morphology in in vitro solid medium system.

Most of values observed such as number of shoots, plant height, number of leaves, number of roots, root length, SPAD (Soil-Plant Analysis Development), fresh weight and dry weight showed a significant change (Supplementary Table 1; Figure 1). The mean net weight rate of the plantlets showed no significant difference in various SNPs concentrations. Plants cultured on 
medium with $1.5 \mathrm{ppm}$ SNPs grew well with almost investigated characteristics reached best as compared to remain SNPs concentrations. When adding higher SNPs concentration - $1.5 \mathrm{ppm}$ in medium, plant growth was slightly lower, severely at $10 \mathrm{ppm}$, number of shoots, plant height, number of leaves were decreased on the contrary SNPs free. Therefore, in in vitro with solid medium system, SNPs with concentration $1.5 \mathrm{ppm}$ is appropriate to Chrysanthemum plant growth.

Some reports confirmed the positive response of SNPs on many plant species. For instance, in vitro Chrysanthemum growth improved at $10 \mathrm{ml} / \mathrm{l}$ of SNPs dose [16], Araucaria excelsa explants grown in MS medium supplemented with SNPs demonstrated that explants grown on media supplemented with SNPs were fresher, had a suitable growth, and maintained their green color on the contrary to SNPs free-MS medium. The authors hypothesized that SNPs indirectly affect plant growth but its inhibitory effects of plant phytohormone ethylene - an inhibitor caused senescence, malformation or some phenomenon as hyperhydicity [8]. According to what reported by Sarmast, findings in Tecomella undulata (Roxb.) Seem. micropropagation demonstrated that the ethylene present in culture vessels during its micropropagation caused shedding of leaves, decreased in chlorophyll content and finally would result in the demise of explants. Providing SNPs in MS medium of T. undulata improved survival percentage of explants and increased mean number of shoot and length of explants [17]. Ethylene resistance mechanism of SNPs due to blocking 1-Aminocyclopropane-1-carboxylic acid (ACC) gene ethylene precursor synthesized gene, subsequently, inhibit ethylene synthesis [17]. On the other hand, in higher concentrations of SNPs negative effects, including seed germination, shoots and roots growth, late flowering and low yield, were observed [18, 19, 20]. Especifically, at $20 \mathrm{ppm}$ of SNPs concentration, yield and antioxidant gene expressions were decreased in Arabidopsis [21], or inhibition of early development at $73.4 \mathrm{ppm}$ [22].

\subsection{Effects of SNPs on Chrysanthemum growth in in vitro liquid medium system}

After 4 weeks of treatment with different concentrations of SNPs in in vitro liquid medium, the results showed that mean of plant height, number of roots, root length, fresh weight, dry weight were statistically different in various concentrations of SNPs (Table 2, Fig. 2). Among them, $1.5 \mathrm{ppm}$ SNPs reached best effects to Chrysanthemum growth which manifested in the best of plant height, number of shoots, number of roots, root length, fresh weight, dry weight and net weight rate as compared to control $(1.12 ; 1.45 ; 3.3 ; 1.3 ; 1.3 ; 1.75$ times, respectively).

Table 2. Effects of SNPs on Chrysanthemum growth in in vitro liquid medium system.

\begin{tabular}{cccccccccc}
\hline $\begin{array}{l}\text { SNP } \\
(\mathrm{ppm})\end{array}$ & $\begin{array}{l}\text { No. } \\
\text { of shoots }\end{array}$ & $\begin{array}{l}\text { Plant } \\
\text { height } \\
(\mathrm{mm})\end{array}$ & $\begin{array}{l}\text { No. } \\
\text { of leaves }\end{array}$ & $\begin{array}{l}\text { No. } \\
\text { of roots }\end{array}$ & $\begin{array}{l}\text { Root } \\
\text { length } \\
(\mathrm{mm})\end{array}$ & $\begin{array}{l}\text { SPAD } \\
(\mathrm{mg} / \mathrm{g})\end{array}$ & $\begin{array}{l}\text { Fresh } \\
\text { weight } \\
(\mathrm{mg})\end{array}$ & $\begin{array}{l}\text { Dry } \\
\text { weight } \\
(\mathrm{mg})\end{array}$ & $\begin{array}{l}\text { Net } \\
\text { rate }\end{array}$ \\
\hline 0 & $10.0^{\mathrm{ab}}$ & $71.7^{\mathrm{b}}$ & $13.0^{\mathrm{a}}$ & $16.0^{\mathrm{b}}$ & $16.0^{\mathrm{d}}$ & $39.2^{\mathrm{ab}}$ & $1221.0^{\mathrm{b}}$ & $32.0^{\mathrm{cd}}$ & $2.62^{\mathrm{b}}$ \\
\hline 0.5 & $8.0^{\mathrm{cd}}$ & $72.7^{\mathrm{b}}$ & $8.3^{\mathrm{c}}$ & $16.0^{\mathrm{b}}$ & $17.7^{\mathrm{d}}$ & $41.3^{\mathrm{a}}$ & $790.7^{\mathrm{c}}$ & $23.7^{\mathrm{d}}$ & $2.99^{\mathrm{b}}$ \\
\hline 1 & $8.3^{\mathrm{c}}$ & $78.3^{\mathrm{ab}}$ & $9.7^{\mathrm{bc}}$ & $16.7^{\mathrm{b}}$ & $57.0^{\mathrm{a}}$ & $34.8^{\mathrm{de}}$ & $1022.0^{\mathrm{b}}$ & $34.7^{\mathrm{abc}}$ & $3.39^{\mathrm{b}}$ \\
\hline 1.5 & $8.7^{\mathrm{bc}}$ & $81.0^{\mathrm{a}}$ & $9.3^{\mathrm{bc}}$ & $23.3^{\mathrm{a}}$ & $53.0^{\mathrm{ab}}$ & $37.7^{\mathrm{bc}}$ & $1590.7^{\mathrm{a}}$ & $74.0^{\mathrm{a}}$ & $4.65^{\mathrm{a}}$ \\
\hline 2 & $11.0^{\mathrm{a}}$ & $83.0^{\mathrm{a}}$ & $13.0^{\mathrm{a}}$ & $17.7^{\mathrm{b}}$ & $42.3^{\mathrm{bc}}$ & $35.9^{\mathrm{cd}}$ & $1470.3^{\mathrm{ab}}$ & $46.3^{\mathrm{b}}$ & $3.15^{\mathrm{b}}$ \\
\hline 3 & $6.7^{\mathrm{de}}$ & $77.0^{\mathrm{ab}}$ & $9.0^{\mathrm{bc}}$ & $17.8^{\mathrm{b}}$ & $63.0^{\mathrm{a}}$ & $35.7^{\mathrm{cd}}$ & $1308.3^{\mathrm{ab}}$ & $38.3^{\mathrm{bc}}$ & $2.93^{\mathrm{b}}$ \\
\hline 5 & $6.3^{\mathrm{e}}$ & $52.7^{\mathrm{c}}$ & $8.7^{\mathrm{c}}$ & $17.0^{\mathrm{b}}$ & $53.3^{\mathrm{ab}}$ & $37.9^{\mathrm{bc}}$ & $1202.0^{\mathrm{b}}$ & $30.0^{\mathrm{cd}}$ & $2.50^{\mathrm{b}}$ \\
\hline 7 & $6.0^{\mathrm{e}}$ & $41.3^{\mathrm{d}}$ & $11.0^{\mathrm{ab}}$ & $15.3^{\mathrm{b}}$ & $39.3^{\mathrm{c}}$ & $33.6^{\mathrm{e}}$ & $836.3^{\mathrm{c}}$ & $27.0^{\mathrm{cd}}$ & $3.23^{\mathrm{b}}$ \\
\hline
\end{tabular}




\begin{tabular}{|c|c|c|c|c|c|c|c|c|c|}
\hline 10 & $6.3^{\mathrm{e}}$ & $31.7^{\mathrm{e}}$ & $8.0^{\mathrm{c}}$ & $15.0^{\mathrm{b}}$ & $36.0^{c}$ & $34.2^{\mathrm{de}}$ & $1005.3^{\mathrm{bc}}$ & $29.3^{\mathrm{cd}}$ & $2.92^{\mathrm{b}}$ \\
\hline
\end{tabular}

Different letters within a column indicate significant differences at $\alpha=0.05$ by Duncan's multiple range tests.
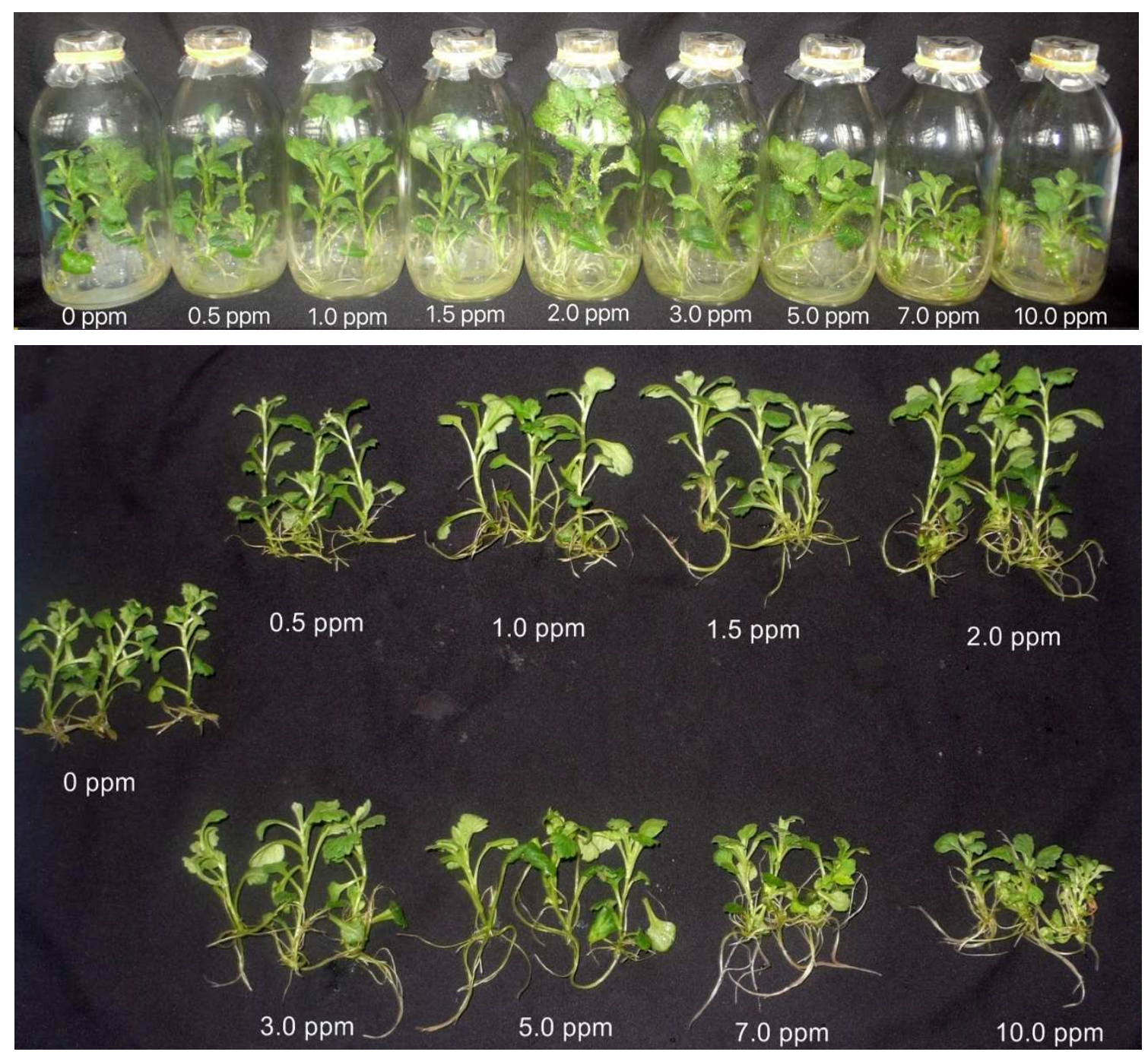

Figure 2. Effects of SNP on Chrysanthemum morphology in in vitro liquid medium system.

When supplying $1 \mathrm{ppm}$ SNPs into medium, although root length reached highest value, others still lower as compared with those cultured on medium supplemented with $1.5 \mathrm{ppm}$ SNPs. When SNPs concentration over $1.5 \mathrm{ppm}$, growth index was suppressed. Particularly, supplied 10 ppm SNPs gained inhibited response in plant. Plant height, number of leaves, number of roots, root length, SPAD, fresh weight, dry weight decreased. In this experiment, hyperhydricity phenomenon on in vitro plantlet in closure vessel was appeared and expressed in lower net weight rate. Exposed SNPs Chrysanthemum at different concentrations were resisted hyperhydricity phenomenon. Especially, $1.5 \mathrm{ppm}$ SNPs help Chrysanthemum gained best as compared to others concentrations and control.

\subsection{Effects of SNPs on Chrysanthemum growth in microponic system}


Table 3. Effects of SNP on Chrysanthemum growth in microponic system.

\begin{tabular}{llllllllll}
\hline $\begin{array}{l}\text { SNP } \\
(\mathrm{ppm})\end{array}$ & $\begin{array}{l}\text { No. } \\
\text { of } \\
\text { shoots }\end{array}$ & $\begin{array}{l}\text { Plant } \\
\text { height( } \\
\mathrm{mm})\end{array}$ & $\begin{array}{l}\text { No. } \\
\text { of } \\
\text { leaves }\end{array}$ & $\begin{array}{l}\text { No. } \\
\text { of roots }\end{array}$ & $\begin{array}{l}\text { Root } \\
\text { length } \\
(\mathrm{mm})\end{array}$ & $\begin{array}{l}\text { SPAD } \\
(\mathrm{mg} / \mathrm{g})\end{array}$ & $\begin{array}{l}\text { Fresh } \\
\text { weight } \\
(\mathrm{mg})\end{array}$ & $\begin{array}{l}\text { Dry } \\
\text { weight } \\
(\mathrm{mg})\end{array}$ & $\begin{array}{l}\text { Net } \\
\text { weight } \\
\text { rate } \\
(\%)\end{array}$ \\
\hline 0 & $10.0^{\mathrm{ab}}$ & $49.0^{\mathrm{b}}$ & $8.7^{\mathrm{a}}$ & $21.0^{\mathrm{a}}$ & $11.3^{\mathrm{ab}}$ & $31.0^{\mathrm{c}}$ & $619.0^{\mathrm{b}}$ & $37.3^{\mathrm{b}}$ & $6.03^{\mathrm{b}}$ \\
\hline 5 & $11.0^{\mathrm{a}}$ & $56.0^{\mathrm{a}}$ & $8.0^{\mathrm{a}}$ & $14.2^{\mathrm{ab}}$ & $13.3^{\mathrm{a}}$ & $39.3^{\mathrm{a}}$ & $708.3^{\mathrm{a}}$ & $45.3^{\mathrm{a}}$ & $6.40^{\mathrm{a}}$ \\
\hline 10 & $8.3^{\mathrm{c}}$ & $47.0^{\mathrm{bc}}$ & $10.0^{\mathrm{a}}$ & $12.0^{\mathrm{b}}$ & $6.7^{\mathrm{bc}}$ & $35.2^{\mathrm{b}}$ & $654.7^{\mathrm{ab}}$ & $44.0^{\mathrm{ab}}$ & $6.72^{\mathrm{a}}$ \\
\hline 15 & $8.7^{\mathrm{bc}}$ & $45.0^{\mathrm{bc}}$ & $8.3^{\mathrm{a}}$ & $8.7^{\mathrm{c}}$ & $4.7^{\mathrm{c}}$ & $34.1^{\mathrm{b}}$ & $569.3^{\mathrm{bc}}$ & $37.0^{\mathrm{b}}$ & $6.50^{\mathrm{b}}$ \\
\hline 20 & $7.3^{\mathrm{c}}$ & $41.7^{\mathrm{d}}$ & $9.0^{\mathrm{a}}$ & $8.3^{\mathrm{c}}$ & $4.0^{\mathrm{c}}$ & $29.8^{\mathrm{c}}$ & $472.7^{\mathrm{c}}$ & $31.3^{\mathrm{c}}$ & $6.63^{\mathrm{ab}}$ \\
\hline
\end{tabular}

Different letters within a column indicate significant differences at $\alpha=0.05$ by Duncan's multiple range tests.

The effects of exposure to different concentrations of SNPs on Chrysanthemum growth are shown in Table 3 and Fig. 3. The overall results indicated that plants which were exposed to different concentrations of SNPs showed significant change in growth characteristics. 5 ppm of SNPs-exposed plant growth is best as compared to the other concentrations. Like in aforementioned in vitro systems, at high concentrations of SNPs, plant growth quite be inhibited. Particularly, $10 \mathrm{ppm}$ of SNPs-exposed plant showed as plants of lowest quality. This result is appropriate with Tung et al. report in 2006, in this study, the authors determined suitable concentration of SNPs in microponic culture on Chrysanthemum is $7.5 \mathrm{ppm}$, if SNPs concentrations were higher than this value, plant growth would become suppressed [23].

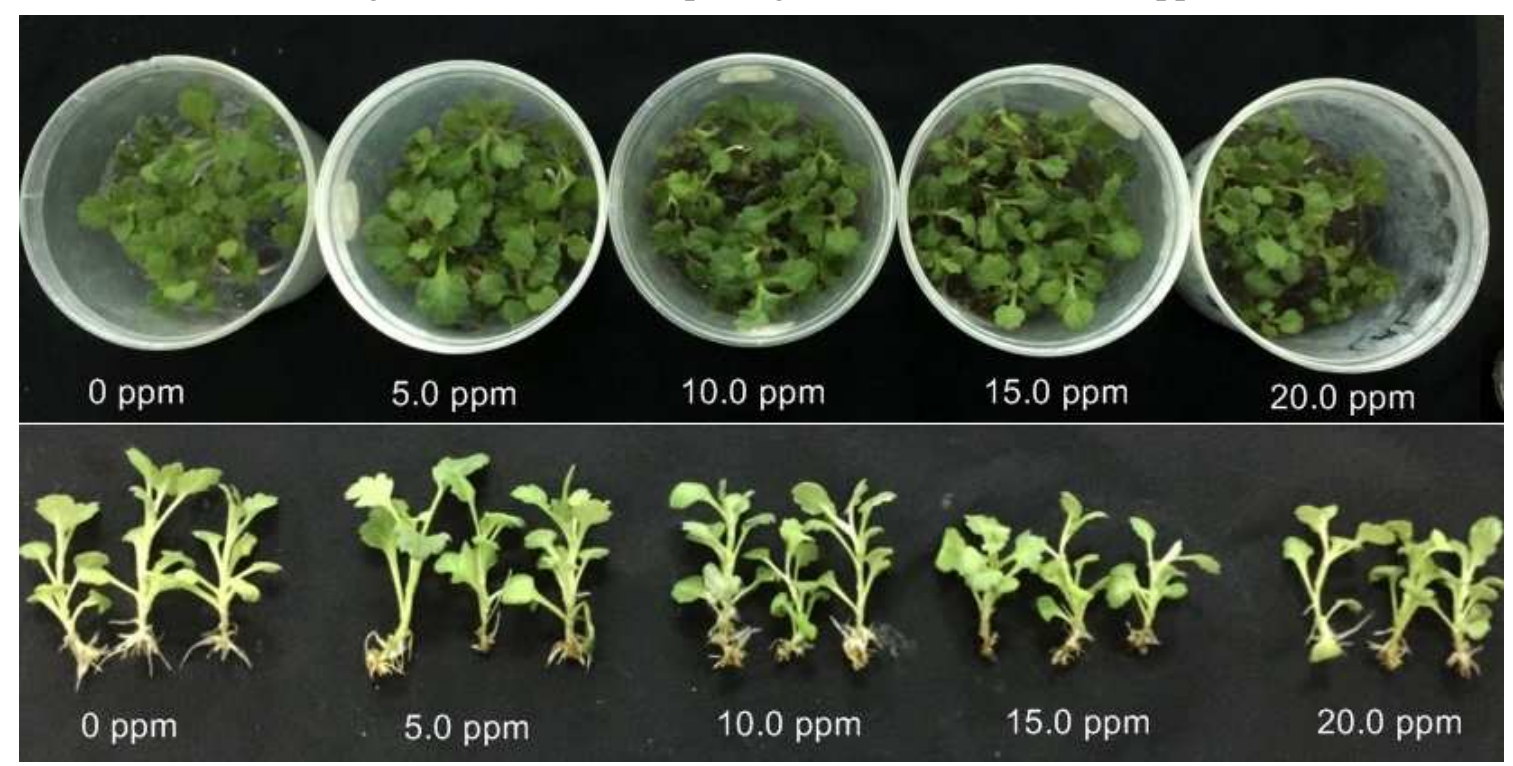

Figure 3. Effects of SNP on Chrysanthemum morphology in microponic system. 
When comparing growth and morphology of Chrysanthemum which were cultured in 3 different systems (in vitro solid medium, in vitro liquid medium and microponic system). The results showed that in vitro liquid medium seem was the best medium for in vitro plant growth due to some of characteristics reach highest as compared to other systems. Due to in aqueous condition, medium can dilute and translocate nutrients easier than in hard condition. Moreover, supported nutrient content (mineral, carbon source) in in vitro liquid medium system was higher in microponic system, consequently, plant growth in in vitro liquid medium system was better. Nevertheless, in vitro liquid medium system with closure vessel condition causes high humidity and hyperhidricity phenomenon expressed in net weight rate lower than in vitro solid medium and microponic system (3.7 and 13.5 times, respectively).

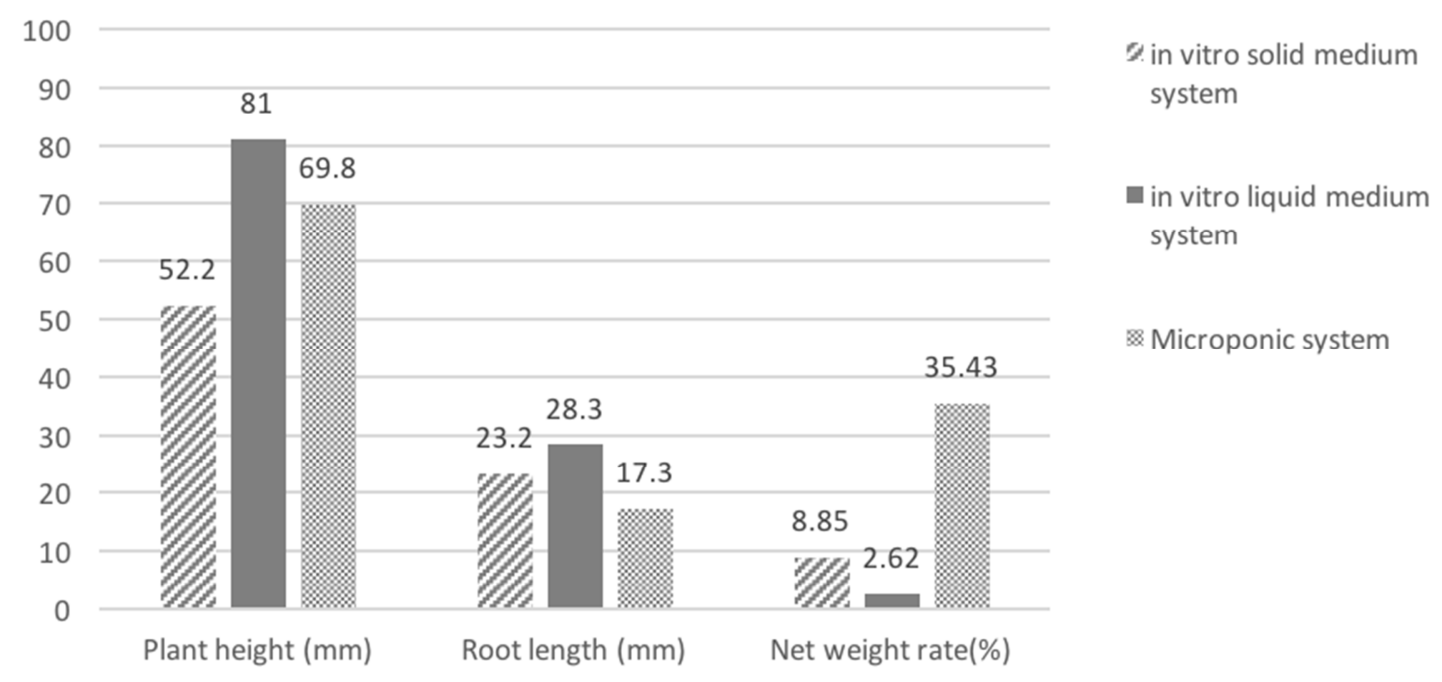

Figure 4. SNPs-exposed Chrysanthemum growth in different cultural systems.

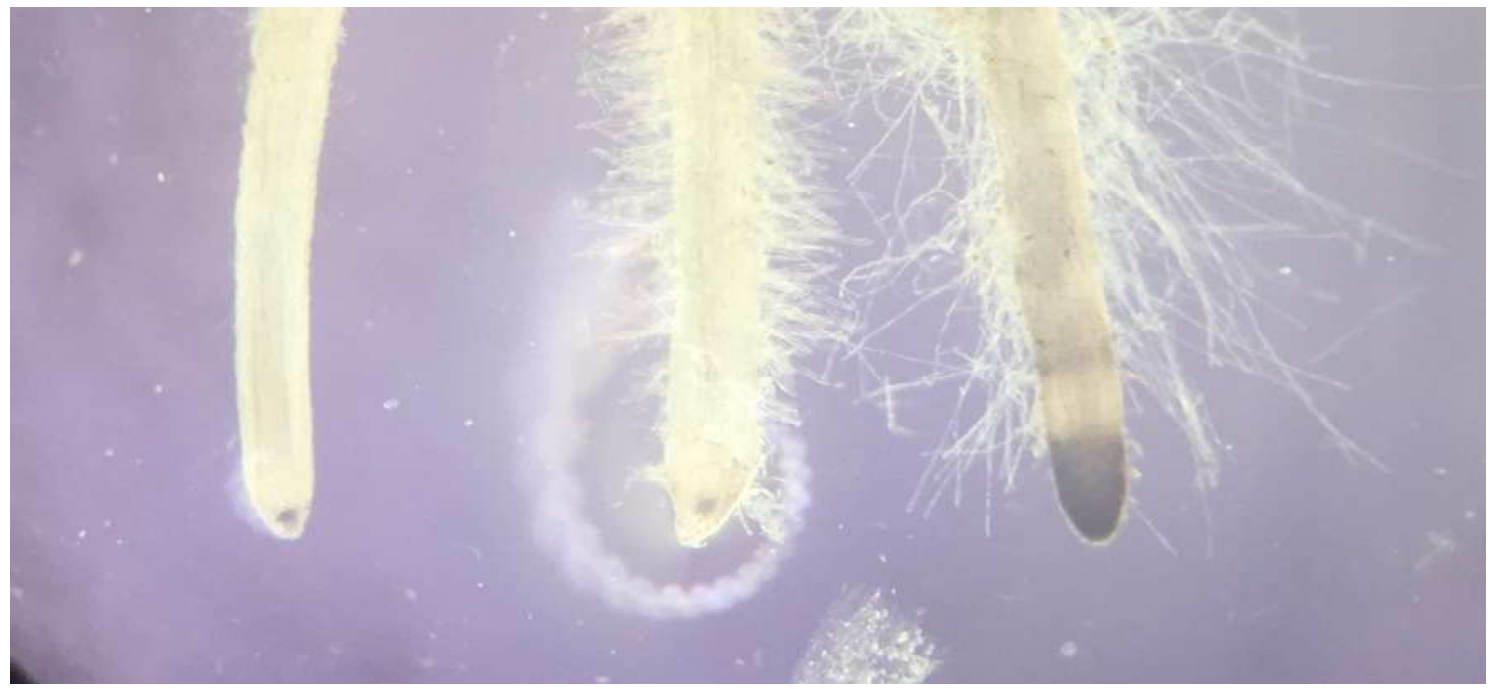

Figure 5. SNPs-exposed root morphology in different cultural system (left to right: in vitro solid medium, in vitro liquid medium and microponic system, respectively). 
Beside of growth values, the alteration in plant morphology under SNP-exposed in different cultural conditions were recognized (Fig. 4). When observed with microscope, root morphologies in different systems have significant change. In liquid medium conditions (in vitro liquid medium and microponic), root-hair developed denser than in solid medium (Fig. 5). Moreover, it was observed that exposure to different concentrations of SNPs has resulted in root tip browning in microponic system. Similar phenomenon was realized in Tung et al. research, they hypothesized that this phenomenon be intensified when SNPs concentration increased and cause root necrosis [23]. Prakash and Ill Min Chung also confirmed root browning by culturing Arabidopsis thaliana in a medium supplemented with SNPs, which occurs due to the accumulation of silver nanoparticles at the root tips [24].

\subsection{SNPs absorption in different cultural systems}

In the first two weeks of culture, the SNPs absorbed capability of Chrysanthemum were very low in all cultured systems. The SNPs uptake was improved then in subsequent culture weeks. Under in vitro solid medium, the ability to absorb SNPs at 20 ppm was only $15.8 \%$ in the first two weeks, but within the next two weeks absorbed-SNPs increased up to $71 \%$ (Fig. 6). This can be explained at the beginning, Chrysanthemum root system still not formed which makes the absorbed-SNPs capacity be limited and only gradually improved in the next stages.

Graphs of absorbed-SNPs rate in in vitro the solid medium system also showed that silver were not completely absorbed at all concentrations over a 4-week period. From 71.7 to $95.9 \%$ and inversely proportional to the SNPs concentration added to the culture medium (Fig. 6).

In in vitro liquid medium systems, at low concentrations (1, 5, $10 \mathrm{ppm})$, silver nanoparticles are completely absorbed after 4 weeks. Especially, 1 ppm SNPs were completely absorbed only for 3 weeks. In this system, absorbed-SNPs capability is also directly proportional to the culture times and inversely proportional to the SNP concentrations. Due to the liquid medium is capable of absorbing growth regulators, dissolving nutrients is better in the solid medium [25]. The study by Suthar et al. also showed that cultured in vitro Boswellia serrata Roxb shoots in liquid medium gave better performance than in solid medium [26]. The authors explained this based on the solubility and flexibility of the environment, which makes the nutrient in the medium easier to be absorbed. In this study, the image was observed under a microscope showing that in a liquid medium, root hairs grow stronger in a solid medium, consequently increases the uptake of nutrients (Fig. 5).

In the microponic system after 4 weeks of culture, except the treatment with 20 ppm SNPssupplementation (only $80.9 \%$ SNPs absorbed), silver nanoparticles were completely absorbed in other treatments. Remaining in all treatments, silver nanoparticles were completely absorbed, in treatments 1 and 5 ppm silver nanoparticles were completely absorbed only after 2; 3 weeks. Silver nanoparticle absorption in this system was directly proportional to the culture time and inversely proportional to the initial silver nanoparticles added to the culture medium, too.

As compared to in vitro liquid medium systems, it was found that in microponic system (aeration filter equipped), SNPs absorbed capability were better at all concentrations. Ventilation is also a condition that enhances the uptake of nutrients from the medium, Ventilation condition enhances air, moisture exchange, promotes water and nutrients uptake from the medium. As compared with other systems, the micro hydroponics system included both growth helpful conditions: liquid medium and ventilated, furthermore saved materials (no sugar added, less than 1/2) and energy (medium not through sterilize by autoclaving) and still guaranteed the utility of silver nanoparticles. 

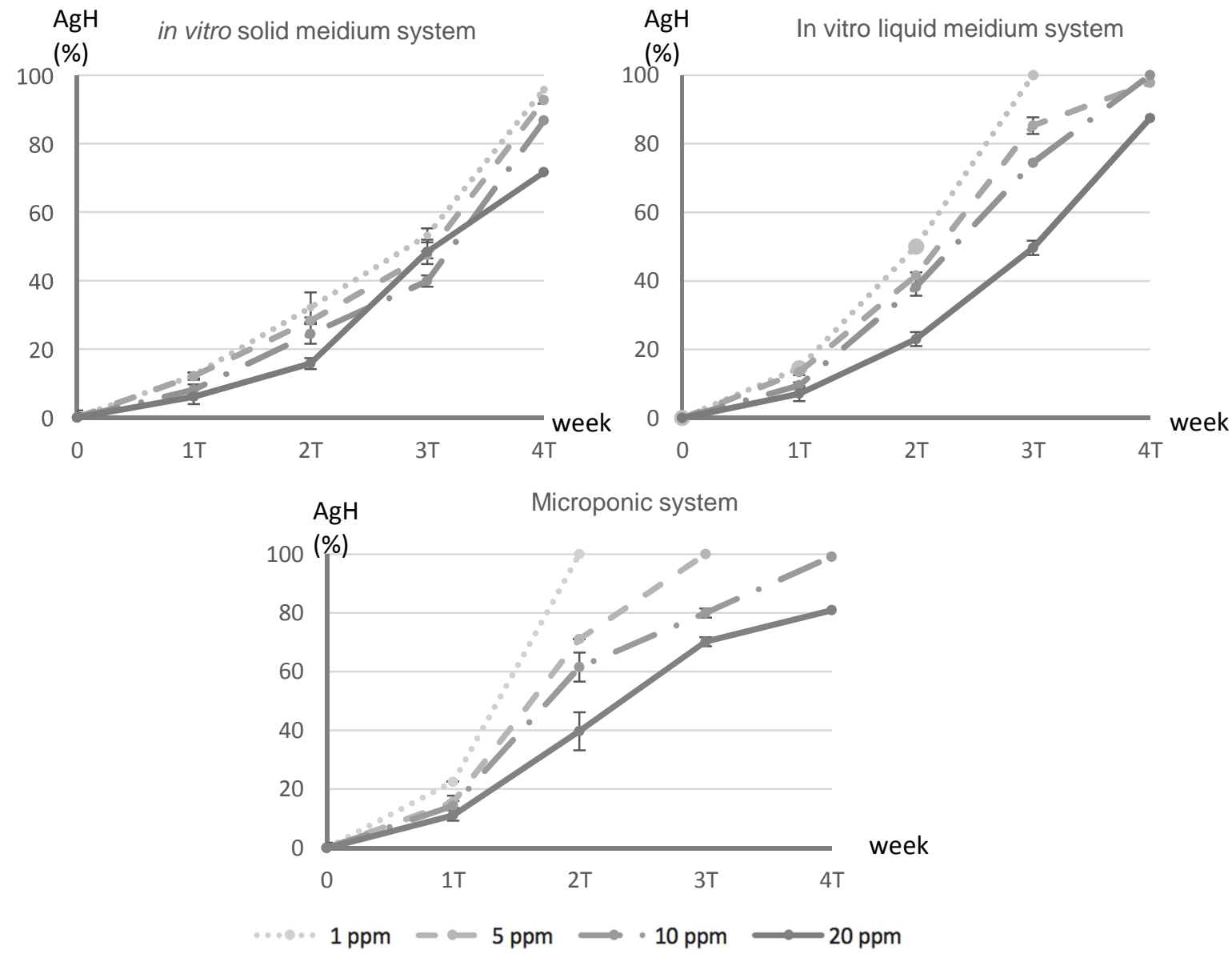

Figure 6. Absorbed-SNPs rate in different culture systems.

\section{CONCLUSION}

Silver nanoparticles are suitable for in vitro Chrysanthemum growth in various culture systems: in vitro solid medium, in vitro liquid medium and microponic system are $1.5 ; 1.5 ; 5$ ppm, respectively. Different culture systems have different SNPs absorbability which directly proportional to the culture time and inversely proportional to the SNPs concentration in the medium. Microponic culture system with liquid medium, ventilated conditions, reduced mineral content and no sugar gained the best results on SNPs absorption, chrysanthemum growth and cost savings.

Acknowledgements: This work was supported by "Research effect of metal nanoparticles to regeneration capability, growth, development and metabolite accumulating" project by Vietnam Academy of Science and Technology under project no. VAST.TĐ.NANO.04/15-18.

\section{REFERENCES}


1. Gholamreza A., Hassan S., Morteza K-K. - Nano silver: a novel nanomaterial for removal of bacterial contaminants in valerian (Valeriana officinalis L.) tissue culture. Acta Physiologiae Plantarum 30 (2008) 709-714.

2. Guggenbichler J. P., Boswald M., Lugauer S., Krall T. - A new technology of microdispersed silver in polyurethane induces antimicrobial activity in central venous catheters, Journal of Infection 27 (1999) 16-23.

3. Jo Y. K., Kim B. H. and Jung G. - Antifungal activity of silver ions and nanoparticles on phytopathogenic fungi, Plant Disease Journal 93 (2009) 1037-1043.

4. Kim S. W., Jung J. H., Lamsal K., Kim Y. S., Min J. S., Lee Y. S. - Antifungal Effects of Silver Nanoparticles (AgNPs) against Various Plant Pathogenic Fungi, Mycobiology Journal 40 (1) (2012) 53-58.

5. Kora A. J., Arunachalam J. - Assessment of antibacterial activity of silver nanoparticles on Pseudomonas aeruginosa and its mechanism of action, World Journal of Microbiology and Biotechnology 27 (2011) 1209-1216.

6. Sahu N., Soni D., Chandrashekhar B. - Synthesis and characterization of silver nanoparticles using Cynodon dactylon leaves and assessment of their antibacterial activity, Bioprocess and Biosystems Engineering 36 (7) (2012) 999-1004.

7. Rodriguez F. I., Esch J. J., Hall A. E., Binder B. M., Schaller G. E., Bleecker A. B. - A copper cofactor for the ethylene receptor ETR1 from Arabidopsis, Science 283 (5404) (1999) 996-998.

8. Sarmast M. K., Salehi H., Khosh-Khui M. - Nano silver treatment is effective in reducing bacterial contaminations of Araucaria excelsa R. Br. var. glauca explants, Acta Biologica Hungarica 62 (4) (2011) 477-84.

9. Zhao X. C., Mathews D. E., Schaller G. E. Effect of ethylene pathway mutations upon expression of the ethylene receptor ETR1 from Arabidopsis, Plant Physiology 130 (4) (2002) 1983-1991.

10. Zhang P., Ma Y., Zhang Z. - Interactions Between Engineered Nanomaterials and Plants: Phytotoxicity, Uptake, Translocation, and Biotransformation. Nanotechnology and Plant Sciences, Springer, Switzerland, 2015, pp. 87.

11. Larue C., Castillo M. H., Sobanska S. - Foliar exposure of the crop Lactuca sativa to silver nanoparticles: evidence for internalization and changes in Ag speciation, Journal of Hazardous Materials 264 (2014) 98-106.

12. Kumari M., Mukherjee A., Chandrasekaran N. - Genotoxicity of silver nanoparticles in Allium cepa, Science of The Total Environment 407 (2009) 5243-5246.

13. Murashige T. and Skoog F. - A revised medium for rapid growth and bioassays with tobacco tissue cultures, Plant Physiology Journal 15 (1962) 473-497.

14. Bhui D. K., Bar H., Sarkar P., Sahoo G. P., De S. P., Misra A. - Synthesis and UV-vis spectroscopic study of silver nanoparticles in aqueous SDS solution, Journal of Molecular Liquids 145 (1) (2009) 33-37.

15. Duncan D. B. - Multiple range and multiple F test. Biometrics 11 (1955) 1-42.

16. Duong Tan Nhut, Ho Thanh Tam, Nguyen Thi Thanh HIen, Le Kim Cuong, Vu Quoc Luan, Nguyen Ba Nam, Nguyen Phuc Huy, Vu Thị Hien, Trinh Thi Huong, Nguyen Hong Hoang, Nguyen Xuan Tuan, Nguyen Thanh Sang, Nguyen Viet Cuong, Do Manh Cuong, 
Nguyen Hoai Chau, Ngo Quoc Buu - Effects of nanosilver on growth of Chrysanthemum sp., Fragaria sp. and Gerbera sp. cultured in vitro, Journal of biotechnology 12 (1) (2014) 103-111 (in Vietnamese).

17. Sarmast M. K., Niazi A., Salehi, H., Abolimoghadam, A. - Silver nanoparticles affect ACS expression in Tecomella undulata in vitro culture. Plant Cell, Tissue and Organic Culture 121 (1) (2015) 227-236.

18. El-Temsah Y. S., Joner E. J. - Impact of Fe and Ag nanoparticles on seed germination and dif- ferences in bioavailability during exposure in aqueous suspension and soil, Environment Toxicology 27(1) (2012) 42-49.

19. Lee W. M., An Y. J., Yoon H., Kweon H. S. - Toxicity and bioavailability of copper nanoparticles to the terrestrial plants mung bean (Phaseolus radiatus) and wheat (Triticum aestivum): plant agar test for water-insoluble nanoparticles, Environment Toxicology Chemical 27(9) (2008) 1915-1921.

20. Lin S., Reppert J., Hu Q., Hudson J. S., Reid M. L., Ratnikova T. A., Rao A. M., Luo H., Ke P. C. - Uptake, translocation, and transmission of carbon nanomaterials in rice plants, Small 5 (10) (2009) 1128-1132.

21. Kaveh R., Li Y. S., Ranjbar S. - Changes in Arabidopsis thaliana gene expression in response to silver nanoparticles and silver ions. Environment Science Technology 47 (2013) 10637 - 10644.

22. Pokhrel L. R., Dubey B. - Evaluation of developmental responses of two crop plants exposed to silver and zinc oxide nanoparticles, Science Total Environment 452-453 (2013) 321-332.

23. Hoang Thanh Tung, Nguyen Phuc Huy, Nguyen Ba Nam, Vu QUoc Luan, Vu Thi Hien, Le Thị Thu Hien, Truong Thi Bich Phuong, Nguyen Hoai Chau, Ngo Tan Buu, Duong Tan Nhut - Effect of silver nanoparticle on Chrysanthemum's growth in microponic system, Journal of Biotechnology 14 (3) 20160 (Accepted) (in Vietnamese).

24. Prakash M., Ill Min Chung - Assessment of silver nanoparticle-induced physiological and molecular changes in Arabidopsis thaliana. Environmental Science and Pollution Research 21 (2014) 8858-8869.

25. Klimaszewska K., Bernier-Cardou M. CyrB. D. R., Sutton C. S. - Influence of gelling agents on culture medium gel strength, water availability, tissue water potential, and maturation response in embryogenic cultures of Pinus strobus L. In Vitro Cellular \& Developmental Biology - Plant 36 (4) (2000) 279 - 286.

26. Suthar R. K., Habibi N., Purohit S. D. - Influence of agar concentration and liquid medium on in vitro propagation of Boswellia serrata Roxb. - Indian Journal of Biotechnology $\mathbf{1 0}$ (2011) 224-227. 